\title{
Ecophysiology of two tropical species in an abandoned eucalypt plantation: effect of plant litter removal and seasonality
}

\author{
Frederico Lage-Pinto ${ }^{1,2 *}$ \\ Elaine Bernini ${ }^{2}$ \\ Jurandi Gonçalves de Oliveira ${ }^{3}$ \\ Marcelo Trindade Nascimento ${ }^{1}$ \\ Angela Pierre Vitória ${ }^{1}$ \\ ${ }^{1}$ Laboratório de Ciências Ambientais, Centro de Biociências e Biotecnologia \\ Universidade Estadual do Norte Fluminense \\ Avenida Alberto Lamego, 2000, CEP 28013-602, Campos dos Goytacazes - RJ, Brasil \\ ${ }^{2}$ Departamento de Engenharia e Meio Ambiente, Centro de Ciências Aplicadas e Educação \\ Universidade Federal da Paraíba, Campus IV \\ Rua Mangueira, s/n, Centro, CEP 58297-000, Rio Tinto - PB, Brasil \\ ${ }^{3}$ Laboratório de Melhoramento Genético Vegetal, Centro de Ciências e Tecnologias Agropecuárias, \\ Universidade Estadual do Norte Fluminense \\ * Autor para correspondência \\ fredlage1@gmail.com
}

Submetido em 19/06/2014

Aceito para publicação em 23/03/2015

\section{Resumo}

Ecofisiologia de duas espécies tropicais em uma plantação abandonada de eucalipto: efeito da remoção da serapilheira e sazonalidade. $O$ efeito da remoção da serapilheira sobre as variáveis do processo fotossintético (trocas gasosas, fluorescência da clorofila $a$, e conteúdo de pigmentos fotossintéticos) das espécies tropicais Xylopia sericea A. St.-Hil. e Siparuna guianensis Aubl. foi avaliado em um plantio abandonado de eucalipto (Corymbia citriodora (Hook.) K.D.Hill \& L.A.S.Johnson (Myrtaceae)) durante os períodos chuvoso e seco, após 5 anos de remoção da serapilheira, na Reserva Biológica União, Rio de Janeiro, Brasil. A remoção da serapilheira não influenciou as respostas ecofisiológicas das espécies. Entretanto, significativa variação sazonal foi verificada. Durante o período seco, a concentração intercelular de $\mathrm{CO}_{2}\left(C_{\mathrm{j}}\right)$, a transpiração $(E)$, e a condutância estomática $\left(g_{\mathrm{s}}\right)$ apresentaram redução nos valores, enquanto a eficiência intrínseca no uso da água (EIUA), a dissipação não-fotoquímica (NPQ) e os carotenoides aumentaram, resultado que sugere uma estratégia protetora contra estresse. No entanto, os valores de $F_{\mathrm{v}} / F_{\mathrm{m}}$ (rendimento quântico máximo) e $F_{\mathrm{m}} / F_{\mathrm{o}}$ (taxa de rendimento da fluorescência pelos estados aberto e fechado) indicam que, mesmo durante o período seco, não houve redução fotoquímica nas espécies. Apenas $S$. guianensis apresentou redução nos valores da taxa de fotossíntese líquida $(A)$ durante o período seco. Os dados sugerem que $X$. sericea é fotossinteticamente mais eficiente sob condições de baixa disponibilidade de água e que a remoção da serapilheira por um período de 5 anos não promove diferenças nos processos ecofisiológicos das espécies analisadas.

Palavras-chave: Corymbia citriodora; Floresta Atlântica; Fotossíntese; Siparuna guianensis, Xylopia sericea 


\section{Abstract}

The effect of the removal of plant litter on photosynthetic variables (gas exchanges, chlorophyll $a$ fluorescence, and content of photosynthetic pigments) of the tropical species Xylopia sericea A. St.-Hil. and Siparuna guianensis Aubl. was evaluated in an abandoned plantation of eucalypt (Corymbia citriodora (Hook.) K.D. Hill \& L.A.S. Johnson (Myrtaceae)). The study was conducted at the União Biological Reserve, Rio de Janeiro State, Brazil during the rainy and dry periods, after five years of litter removal. The removal of plant litter did not influence the ecophysiological responses of the species. There was however significant seasonal variation. During the dry period, intercellular $\mathrm{CO}_{2}$ concentration $\left(C_{\mathrm{i}}\right)$, transpiration $(E)$, and stomatal conductance $\left(g_{s}\right)$ were decreased, while intrinsic efficiency of water use (IWUE), non-photochemical quenching (NPQ), and carotenoid values increased, suggesting a protective strategy against stress. Nevertheless, the values for $F_{\mathrm{v}} / F_{\mathrm{m}}$ (maximum quantum efficiency) and $F_{\mathrm{m}} / F_{\mathrm{o}}$ (ratio of fluorescence yields for open and closed states) indicated that even during the dry period there was no reduction in photochemical activity in these species. Only S. guianensis exhibited a reduced net photosynthetic rate $(A)$ during the dry period. The data indicated that $X$. sericea was photosynthetically more efficient under conditions of low water availability and that a 5 -year period of plant litter removal failed to produce differences in ecophysiological processes in the species analyzed.

Key words: Atlantic forest; Corymbia citriodora; Photosynthesis; Siparuna guianensis; Xylopia sericea

\section{Introduction}

The Atlantic Forest in Brazil, which once covered more than one million square kilometers, has been reduced to $12 \%$ of its original area (RIBEIRO et al., 2009). Given the current state of degradation of this biome, we are confronted with the need to conserve and make sustainable use of its remaining stands, expand native forest plantations, connect fragments, and restore abandoned and degraded areas. With the objective of minimizing pressures on native forests and recovering degraded areas, all while meeting increasing demands for wood and bioenergy; many countries have begun expanding the systematic planting of exotic tree species with rapid initial growth patterns (FEYERA et al., 2002; FONSECA et al., 2009).

Studies have demonstrated that eucalypt plantations can facilitate natural regeneration, thus helping to restore native forests (FEYERA et al., 2002; FERREIRA et al., 2007; NÓBREGA et al., 2008). Some species of eucalypt, however, such as Corymbia citriodora (Hook.) K.D. Hill \& L.A.S. Johnson (Myrtaceae), have been considered harmful due to their allelopathic effects (NISHIMURA et al., 1984; ZHANG; FU, 2010). In addition, eucalypt leaf litter is considered to be of low nutritional quality (VILLELA et al., 2004) due to the elevated $\mathrm{C} / \mathrm{N}$ ratio, which interferes with decomposition rates and nutrition cycling.
Plant litter is essential for the introduction of nutrients into the soil-vegetation system, and is thus an important factor in healthy forest ecosystem functioning (CHAPIN III et al., 2002; PRESCOTT et al., 2004; KNORR et al., 2005). Plant litter is a determinant in the dynamics and structure of plant communities, because of its effects on germination and plant establishment (XIONG; NILSSON, 1999). The plant litter layer protects the soil against erosion, leaching, and sudden changes in temperature and humidity (MO et al., 2003; SAYER, 2006; SANGHA et al., 2006), as well as furnishing a habitat and substrate for soil fauna (ATTIGNON et al., 2004) and decomposition microorganisms (RUF et al., 2006).

In southeastern Brazil, extensive tracts of the Atlantic Forest have been substituted by monoculture tree species (SUGUITURU et al., 2011). Brazil is currently the world leader in total occupied area of eucalypt plantations (GIT FORESTRY CONSULTING, 2009). The União Biological Reserve (REBIO União), located in the southeastern region of Brazil, has abandoned plantations of $C$. citriodora in which native species are regenerating in understory. However, studies indicate that these plants regenerate very slowly and have low species diversity (EVARISTO, 2008). For example, Xylopia sericea (Annonaceae) and Siparuna guianensis (Siparunaceae), both in the initial stage of ecological succession, are among the native species 
that occur in greatest abundance (EVARISTO et al., 2011). An experiment, involving manipulation of plant litter over the long term, was initiated in this reserve in 2004, and it demonstrated that the plant litter functions as a physical barrier against seed germination, while the removal of plant litter generally enhances the recruitment and survival of native species seedlings (RIBEIRO, 2007). On the other hand, in the same area studied, D.M. Villela (unpublished data) obtained results attesting to a negative effect related to the removal of plant litter, with soil showing lower $\mathrm{C}$ and $\mathrm{N}$ values and $\mathrm{C} / \mathrm{N}$ ratio when compared with the controls.

Just as with nutrient concentration, water availability of the soil may limit the establishment and productivity of the plants (CAVENDER-BARES; BAZZAZ, 2004). Litter plays an important role in water conservation during dry conditions (FOWLER, 1986; 1988). Water stress can affect the photosynthetic process through stomatal and non-stomatal effects. The stomatal effect, considered a primary event, leads to a lower concentration of internal $\mathrm{CO}_{2}$, reducing its assimilation in chloroplasts (FARIA et al., 1996). The non-stomatal effects refer to perturbations in photochemical (BAKER, 1993) and biochemical (LU; ZANG, 1999) processes.

Studies focusing on the management of plant litter over long periods are in their initial phases (WOOD et al., 2009; SAYER; TANNER, 2010) and require the consideration of ecophysiological aspects to better understand the resultant nutritional adjustments and/ or deficiencies in different types of soils. With this in mind, the objectives of this work were: (1) to examine the effect of plant litter removal on the ecophysiological attributes of the species $X$. sericea and $S$. guianensis in an abandoned plantation of eucalypt (C. citriodora), and (2) to examine the occurrence of seasonal variations among the ecophysiological attributes and their relation to plant litter removal.

\section{Material and Methods}

\section{Study area, plant material, and sampling period}

The União Biological Reserve, Rio de Janeiro, Brazil $\left(22^{\circ} 27^{\prime} \mathrm{S}\right.$ and $\left.42^{\circ} 02^{\prime} \mathrm{W}\right)$ consists of $2,550 \mathrm{ha}$, with 2,200 ha of coastal lowland and submontane Atlantic Forest classified as dense ombrophilous forest (VELOSO et al., 1991). In addition, approximately 220 ha are covered with eucalypt (C. citriodora) plantations of different ages (MMA-ICMBIO, 2008). The climate is tropical humid with an average annual temperature of $25^{\circ} \mathrm{C}$, rainfall on the order of $1,620 \mathrm{~mm}^{2}$ year ${ }^{-1}$, with $75 \%$ of rainfall concentrated in the period of October to March (Figure 1).

FIGURE 1: Precipitation and temperature between October 2009 and September 2010 for the weather station at União Biological Reserve, Brazil. $\Delta$ minimum temperature, $\boldsymbol{\Delta}$ maximum temperature (Source: LAGE-PINTO et al., 2012).

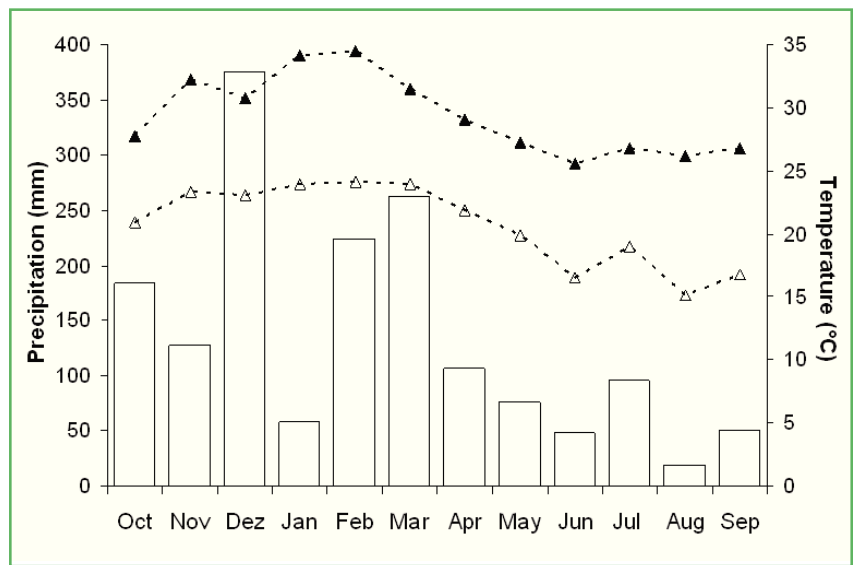

This study was conducted on plots located in an 11.44-ha eucalypt plantation, with spacing of $3 \mathrm{~m} \mathrm{x}$ $3 \mathrm{~m}$ age of 41 years, which had received no forestry management intervention since 1996. According to Evaristo et al. (2011), the density of individuals per hectare was 1,010 with a total of 17 species $(X$. sericea, S. guianensis, Guatteria campestris R.E.Fr., Piptocarpha macropoda (DC.) Baker, Cybistax antisyphilitica (Mart.) Mart., Jacaranda puberula Cham., Sparattosperma leucanthum (Vell.) K.Schum., Erythroxylum pulchrum A.St.-Hil., Lacistema pubescens Mart., Licaria 
bahiana H.W.Kurtz, Byrsonima sericea DC., Miconia cinnamomifolia (DC.) Naudin, Guarea macrophylla Vahl, Eugenia supraaxillaris Spring, Myrcia anceps (Spreng.) O.Berg, Cupania oblongifolia Mart., and Cupania racemosa (Vell.) Radlk.). The photosynthetic photon flux density (PPFD) was 196.9 $\pm 49.9 \mu \mathrm{mol} \mathrm{m}^{-2}$ $\mathrm{s}^{-1}$ during the rainy period and $178.9 \pm 45.4 \mu \mathrm{mol} \mathrm{m} \mathrm{m}^{-2} \mathrm{~s}^{-1}$ during the dry period, while the average air temperature (understory level) was $32.1 \pm 0.8^{\circ} \mathrm{C}$ during the rainy period and $27.5 \pm 0.5^{\circ} \mathrm{C}$ during the dry period. In August 2004, six plots measuring $5 \mathrm{~m}$ x $20 \mathrm{~m}$ were randomly demarcated. In three of the plots, the plant litter was maintained (control treatment), and in the other three plots, the plant litter layer was removed every 15 days (removal treatment).

The tree species $X$. sericea and $S$. guianensis occur naturally with large numbers of individuals in the understory of this plantation in both treatment areas (EVARISTO, 2008). In total, nine individuals of $X$. sericea $(1.5-2.0 \mathrm{~m})$ and $S$. guianensis $(1.5-2.0 \mathrm{~m})$ were selected from each treatment (three individuals per plot). Gas exchange, chlorophyll $a$ fluorescence, and level of photosynthetic pigments in young leaves (totally expanded and collected from the second node) were measured twice during the rainy period (November 2009 and February 2010) and the dry period (July 2010 and September 2010). The results for the control treatment collection are from the data collected by Lage-Pinto et al. (2012).

\section{Gas exchange}

Measurements were determined with a portable photosynthesis system, model CIRAS 2 (PP Systems International, Inc. Amesbury, MA, USA) with the use of a leaf cuvette with an area of $1.7 \mathrm{~cm}^{2}$. LED unit (PLC6 (U)) was used for light control. Data were collected at ambient conditions of temperature $(28 \pm$ $3^{\circ} \mathrm{C}$ ) and relative humidity $(70 \%)$. Photosynthetic light response curves were determined for PPFD between 0

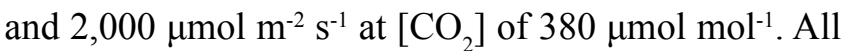
gas exchange measurements were taken after steady rates of photosynthesis and transpiration were observed, usually within 15 to $25 \mathrm{~min}$ after exposure to an altered light intensity. The A/PPFD light response curve was used to determine light saturated photosynthesis for both species $\left(700 \mu \mathrm{mol} \mathrm{m} \mathrm{m}^{-2} \mathrm{~s}^{-1}\right.$ for $X$. sericea and 1,100 $\mu \mathrm{mol} \mathrm{m} \mathrm{m}^{-2} \mathrm{~s}^{-1}$ for $S$. guianensis). After determination of light saturated photosynthesis, the following parameters were obtained: net photosynthetic rate $(A)$, intercellular $\mathrm{CO}_{2}$ concentration $\left(C_{\mathrm{i}}\right)$, stomatal conductance $\left(g_{\mathrm{s}}\right)$, and transpiration $(E)$. The intrinsic water use efficiency (IWUE) was calculated as the ratio $A / g_{\text {s }}$. Measurements were taken between 8:00 and 10:30 AM during the period of maximum stomatal conductance. Each measurement was performed on two fully expanded mature leaves per individual.

\section{Chlorophyll a fluorescence}

Chlorophyll $a$ fluorescence was measured in situ between 11:00 AM and 12:00 PM with the use of a portable modulated fluorometer, model FMS2 (Hansatech Instruments, Ltd, UK). The measurements were done on the same leaves used for gas exchange analysis. After 30 min of adaptation to the dark (with the use of leaf clips), the leaves were exposed to red light modulated at low intensity (approximately $6 \mu \mathrm{mol}$ $\mathrm{m}^{-2} \mathrm{~s}^{-1}$ at $660 \mathrm{~nm}$ ) followed by a pulse of $0.8 \mathrm{~s}$ of actinic light $\left(6,000 \mu \mathrm{mol} \mathrm{m} \mathrm{m}^{-2} \mathrm{~s}^{-1}\right)$, modified from Genty et al. (1989) and Van Kooten and Snel (1990). The following chlorophyll $a$ fluorescence emission parameters were determined: $F_{\mathrm{o}}$ (minimum fluorescence), $F_{\mathrm{m}}$ (maximum fluorescence), and $F_{\mathrm{v}}$ (variable fluorescence), $F_{\mathrm{v}} / F_{\mathrm{m}}$ (maximum quantum efficiency of photosystem II), qL (photochemical quenching-Kramer lake model), NPQ (non-photochemical quenching) and $F_{\mathrm{m}} / F_{\mathrm{o}}$ (the ratio of fluorescence yields for open and closed states).

\section{Photosynthetic pigments}

Three leaf discs were removed from the nine plants evaluated (mature leaves) of each treatment area and their pigments were extracted with $5 \mathrm{~mL}$ of dimethyl sulfoxide (DMSO). After five days, the extract was analyzed in a spectrophotometer (480, 649, and 665 $\mathrm{nm})$. Chlorophyll $a$, chlorophyll $b$, and carotenoids 
were measured according to Wellburn (1994). The concentrations of total chlorophylls (chlorophyll $a+b$ ), chlorophyll $a / b$, and total chlorophylls/carotenoids were calculated. All laboratory procedures were carried out under low light conditions.

\section{Statistical analyses}

The ecophysiological data were separated into two groups, one for the rainy period (November 2009 and February 2010) and one for the dry period (July 2010 and September 2010), resulting in a sample number of 18 for each treatment area. The results of the gas exchange, chlorophyll $a$ fluorescence, and level of photosynthetic pigments were subjected to ANOVA for three factors, and the means were compared with the Tukey test.

\section{Results}

The variables related to gas exchange did not show significant differences between the control and treatment with plant litter removal areas for $X$. sericea or S. guianensis (Figure 2). However, there was seasonal variation; in the dry period, the variables $C_{i}, g_{\mathrm{s}}$, and $E$ (Figures 2B, 2C, and 2E) showed lower values, while IWUE (Figure 2E) exhibited higher values for

FIGURE 2: Gas exchanges (mean \pm standard error; $\mathrm{n}=18$ ) of $X$. sericea and $S$. guianensis in the control and plant litter removal treatment areas during the rainy period ( $\square$ ) and dry period ( $\square$ ), in the União Biological Reserve, RJ, Brazil. (A) net photosynthetic rate $(A),(\mathrm{B})$ intercellular $\mathrm{CO}_{2}$ concentration $\left(C_{\mathrm{j}}\right),(\mathrm{C})$ stomatal conductance $\left(g_{\mathrm{s}}\right),(\mathrm{D})$ transpiration $(E)$, and $(\mathrm{E})$ intrinsic water use efficiency $(I W U E)$. Lower-case letters compare periods for the same species within each treatment area. Different letters indicate significant differences $(p \leq 0.05)$. Asterisk $\left(^{*}\right)$ indicates significant differences $(p \leq 0.05)$ between species within the same treatment area and period. There were no significant differences between the treatment areas.

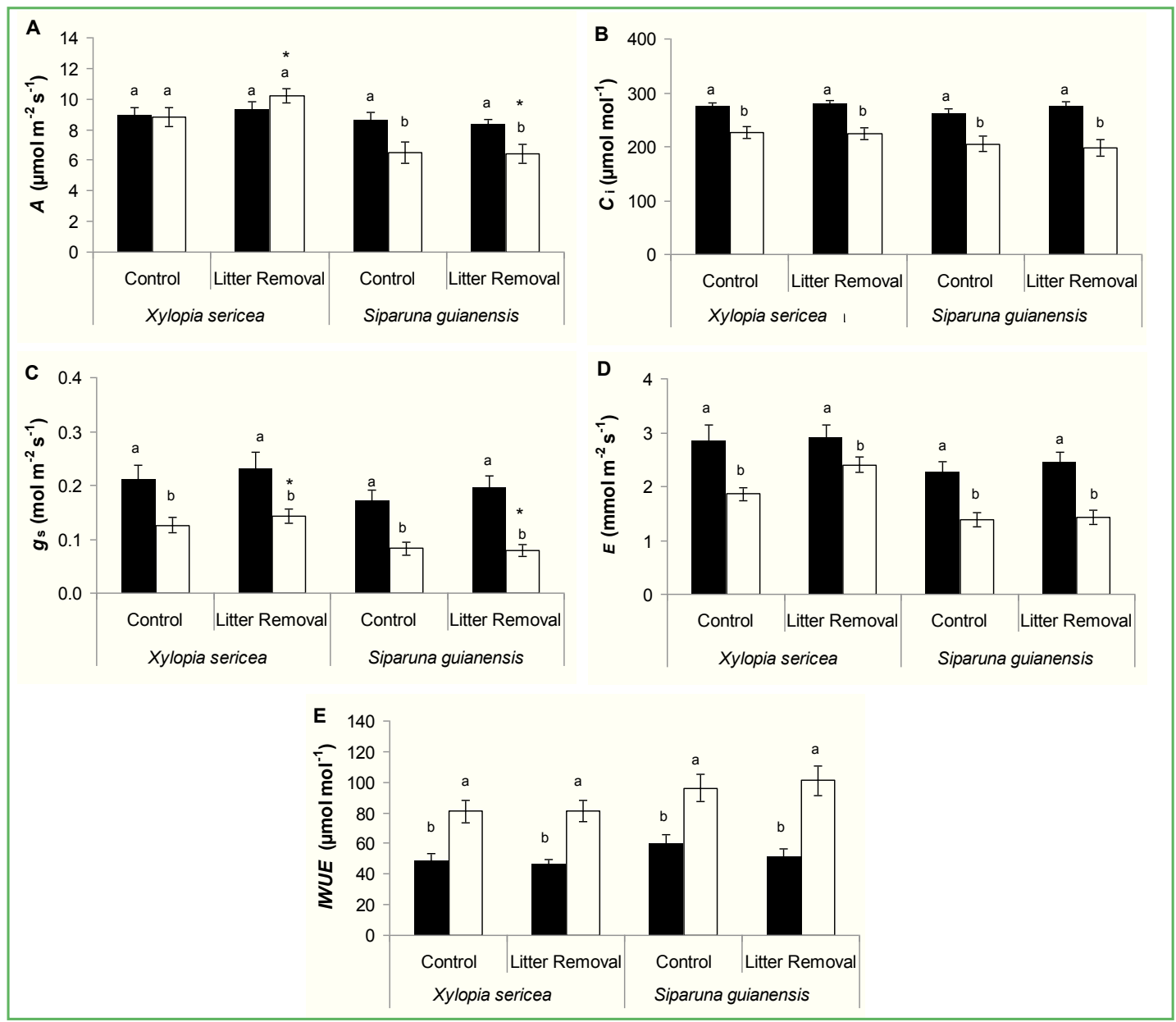


both species. Only $S$. guianensis showed a significant reduction in $A$ during the dry period in both treatment areas (Figure 2A). A comparison of the species revealed higher $A$ and $g_{\mathrm{s}}$ values in $X$. sericea in the treatment area with plant litter removal during the dry period.

The chlorophyll $a$ fluorescence parameters showed no significant differences between the treatment areas for either $X$. sericea or $S$. guianensis (Figure 3). The parameters $F_{\mathrm{o}}, F_{\mathrm{m}}, F_{\mathrm{v}} / F_{\mathrm{m}}$, and $F_{\mathrm{m}} / F_{\mathrm{o}}$ did not exhibit seasonal variation (Figures 3A, 3B, 3C, and 3D). In $S$. guianensis, NPQ was higher during the dry period in both treatment areas (Fig. 3F). When comparing the species, $S$. guianensis had a higher $F_{\mathrm{m}}$ value in the litter removal treatment during the dry period (Figure $3 \mathrm{~B}$ ).

FIGURE 3: Parameters of chlorophyll $a$ fluorescence (mean \pm standard error; $\mathrm{n}=18$ ) of $X$. sericea and $S$. guianensis in the control and plant litter removal treatment areas during the rainy period (घ) and dry period ( $\square$ ), in the União Biological Reserve, RJ, Brazil. (A) $F_{\mathrm{o}}$, minimum fluorescence; (B) $F_{\mathrm{m}}$, maximum fluorescence; (C) $F_{\mathrm{v}} / F_{\mathrm{m}}$, maximum quantum yield of FSII; (D) $F_{\mathrm{m}} /$ $F$, ratio of fluorescence yields for open and closed states; (E) qL, photochemical quenching (lake model), and (F) NPQ, nonphotochemical quenching coefficient. Lower-case letters compare periods for the same species within each treatment area. Different letters indicate significant differences $(p \leq 0.05)$. Asterisk $(*)$ indicates significant differences $(p \leq 0.05)$ between species within the same treatment area and period. There were no significant differences between the treatment areas.

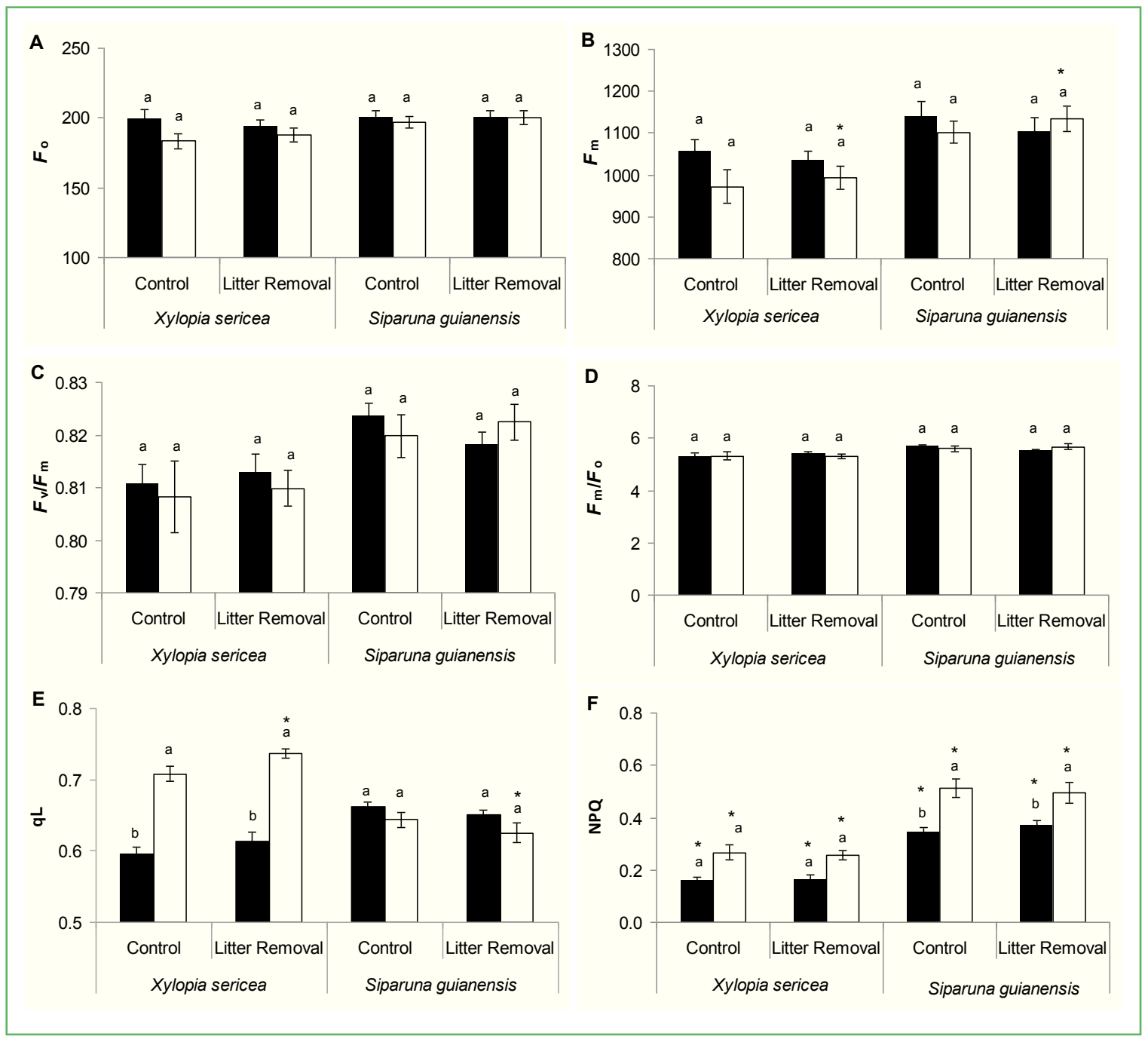


This species also showed higher NPQ levels in both treatment areas during both the dry and rainy periods (Figure $3 \mathrm{~F}$ ). $X$. sericea exhibited higher $\mathrm{qL}$ in the treatment area with plant litter removal during the dry period (Figure 3E).

The photosynthetic pigment levels are presented in Table 1. There were no significant differences between the treatments (control and litter removal) for either species. Seasonal variations were observed with the exception of chlorophyll $b$. Chlorophyll $a$ values were higher during the dry period, with the exception of $S$. guianensis in the treatment area with plant litter removal. Carotenoid content was higher for both species and treatment areas (control and litter removal) during the dry period, consequently reducing the total chlorophylls/ carotenoids ratio. The chlorophyll $a / b$ ratio was higher during the dry period, except for $S$. guianensis in the control area. The highest level of total chlorophylls occurred in $X$. sericea during the dry period (treatment area with plant litter removal). When comparing the two species, only the level of carotenoids was higher in $X$. sericea in the treatment area with plant litter removal during the dry period.

\section{Discussion}

The removal of plant litter for 5 years did not affect photosynthetic parameters. The litter layer acts as a physical barrier, intercepting direct rainfall and solar radiation (BENKOBI et al., 1993; PONGE et al., 1993), reducing evaporation from the soil surface, and thus regulates soil microclimate (SAYER, 2006). Scalon et al. (2014) in a manipulation experiment (four years), showed that the removal of litter caused a decrease in $g$ s and $E$ in plants of the Cerrado, indicating that savanna woody plants responded promptly to litter manipulation by adjusting leaf water loss, which suggests that in the short term, changes in the amount of litter in Cerrado ecosystems can affect the soil water availability to the plant community. However, the authors emphasize that changes in some physiological traits may be dependent on a time-response to treatment, so 4 years may not be sufficient time to allow us to observe a significant response, as in the present study. The litter layer is also an important source of nutrients for tropical ecosystems (VITOUSEK, 1984). However, as for the photosynthetic parameters, new and mature leaves of $X$. sericea did not show alterations in the concentrations of $\mathrm{C}, \mathrm{N}, \mathrm{K}, \mathrm{P}$, and $\mathrm{Mg}$ resulting from the removal of plant litter 4 years after

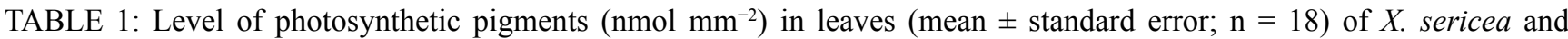
$S$. guianensis in the control and plant litter removal treatment areas during the rainy and dry periods in the União Biological Reserve, RJ, Brazil. Chl, Chlorophyll; $\mathrm{C}_{\mathrm{x}+\mathrm{c}}$, carotenoids. Lower-case letters compare rainy and dry period for the same species within each treatment area. Different letters indicate significant differences $(p \leq 0.05)$. Asterisk $(*)$ indicates significant differences $(p \leq 0.05)$ between species within the same treatment area and period. There were no significant differences between treatment areas.

\begin{tabular}{|c|c|c|c|c|c|c|c|}
\hline & & Chl a & $C h l b$ & $C_{x+c}$ & $C h l a / b$ & $C h l_{\text {Total }} / C_{x+c}$ & $C h l_{\text {Total }}$ \\
\hline \multirow{6}{*}{ 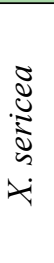 } & Control & & & & & & \\
\hline & Rainy & $0.29 \pm 0.005 \mathrm{~b}$ & $0.11 \pm 0.005 \mathrm{a}$ & $0.06 \pm 0.001 \mathrm{~b}$ & $2.7 \pm 0.1 \mathrm{~b}$ & $7.3 \pm 0.2 \mathrm{a}$ & $0.40 \pm 0.009 \mathrm{a}$ \\
\hline & Dry & $0.36 \pm 0.015 \mathrm{a}$ & $0.11 \pm 0.007 \mathrm{a}$ & $0.07 \pm 0.003 \mathrm{a}$ & $3.5 \pm 0.1 \mathrm{a}$ & $6.5 \pm 0.1 \mathrm{~b}$ & $0.47 \pm 0.022 \mathrm{a}$ \\
\hline & Litter Removal & & & & & & \\
\hline & Rainy & $0.30 \pm 0.010 \mathrm{~b}$ & $0.10 \pm 0.004 \mathrm{a}$ & $0.06 \pm 0.002 b$ & $2.9 \pm 0.1 \mathrm{~b}$ & $7.0 \pm 0.1 \mathrm{a}$ & $0.41 \pm 0.014 b$ \\
\hline & Dry & $0.39 \pm 0.020 \mathrm{a}$ & $0.11 \pm 0.010 \mathrm{a}$ & $0.08 \pm 0.004 \mathrm{a} *$ & $4.1 \pm 0.3 \mathrm{a}$ & $6.3 \pm 0.1 \mathrm{~b}$ & $0.50 \pm 0.031 \mathrm{a}$ \\
\hline \multirow{6}{*}{ 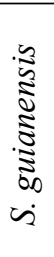 } & Control & & & & & & \\
\hline & Rainy & $0.33 \pm 0.010 \mathrm{~b}$ & $0.11 \pm 0.004 \mathrm{a}$ & $0.06 \pm 0.002 \mathrm{~b}$ & $3.1 \pm 0.1 \mathrm{a}$ & $7.3 \pm 0.1 \mathrm{a}$ & $0.44 \pm 0.013 \mathrm{a}$ \\
\hline & Dry & $0.39 \pm 0.017 \mathrm{a}$ & $0.12 \pm 0.007 \mathrm{a}$ & $0.08 \pm 0.004 \mathrm{a}$ & $3.3 \pm 0.1 \mathrm{a}$ & $6.7 \pm 0.1 \mathrm{~b}$ & $0.51 \pm 0.023 \mathrm{a}$ \\
\hline & Litter Removal & & & & & & \\
\hline & Rainy & $0.28 \pm 0.009 \mathrm{a}$ & $0.10 \pm 0.003 \mathrm{a}$ & $0.05 \pm 0.003 \mathrm{~b}$ & $2.7 \pm 0.1 \mathrm{~b}$ & $7.3 \pm 0.2 \mathrm{a}$ & $0.38 \pm 0.012 \mathrm{a}$ \\
\hline & Dry & $0.34 \pm 0.015 \mathrm{a}$ & $0.10 \pm 0.010 \mathrm{a}$ & $0.06 \pm 0.004 \mathrm{a} *$ & $3.9 \pm 0.3 \mathrm{a}$ & $6.5 \pm 0.1 \mathrm{~b}$ & $0.44 \pm 0.024 \mathrm{a}$ \\
\hline
\end{tabular}


the initiation of this manipulation in the União Biological Reserve (CAMARA, 2012).

According to Sayer (2006), some long-term studies done on plant litter manipulation found reduced concentrations of $\mathrm{P}, \mathrm{K}$, and $\mathrm{Mg}$ in soil only after 12 and 15 years in temperate regions. Although it was expected that the removal of plant litter would promote the rapid reduction of nutrient concentrations in tropical forests in their studies of a mature tropical forest and a secondary forest in Puerto Rico over two years, Wood et al. (2009) also found no forest or nutrient cycling productivity response as result of such manipulation. Sayer and Tanner (2010) obtained similar findings to those of Wood et al. (2009) in another study on plant litter manipulation on a large scale in a tropical lowland forest in Panama conducted over 5 years. The authors suggest that the experimentation period may not have been long enough to influence the growth of the plants (127 species), and that a longer study period may be required.

Significant seasonal variation in the photosynthetic parameters was observed. Under conditions of low water availability during dry period, the stomatal closing reduced transpiration and reduced internal concentrations of $\mathrm{CO}_{2}$ as well as higher IWUE in the leaves of both tree species. Under conditions of low water availability, stomatal opening is one of the first plant processes to be affected, causing a reduction in gas exchanges (NILSEN; ORCUTT, 1996; BUCKLEY et al., 1999).

Although both species showed significant seasonal variation for the variables $C_{\mathrm{i}}, g_{\mathrm{s}}, E$, and $I W U E$, only $S$. guianensis exhibited a significant reduction in the net photosynthetic rate $(A)$ during the dry period. Young plants of Euterpe oleracea (CALBO; MORAES, 2000) and Carapa guianensis (GONÇALVES et al., 2009) have shown similar responses when subjected to a lack of irrigation in a greenhouse. Similar results were also reported for the pioneer Byrsonima sericea in field conditions in the União Biological Reserve (SILVA et al., 2010). In the present study, a comparison of the species revealed that in the treatment area with plant litter removal, $X$. sericea plants showed higher $A$ values in the dry period.
In some cases a reduction in $A$ values may be attributed to effects triggered by photochemical (supply of ATP and NADPH to the Calvin-Benson cycle) and/ or biochemical problems (rubisco concentration and enzyme activity; regeneration of RuBP by the CalvinBenson cycle) (REIS; CAMPOSTRINI, 2008). In the present study, lower qL values in $S$. guianensis were observed when compared with $X$. sericea in the treatment area with plant litter removal, indicating that $X$. sericea showed a higher fraction of oxidized PSII based on the "lake model" (KRAMER et al., 2004). Nevertheless, the values of $F_{\mathrm{o}}$ and $F_{\mathrm{m}}$ indicated lack of damage to the center of the reaction of PSII $\left(\mathrm{P}_{680}\right)$ (MAXWELL; JOHNSON, 2000; ROSENQVIST et al., 1991).

According to Björkman and Demmig (1987), the $F_{\mathrm{v}} / F_{\mathrm{m}}$ ratio in healthy plants should be around $0.83 . F_{\mathrm{v}} / F_{\mathrm{m}}$ ratio reflects the potential quantum efficiency of PSII and is used as a sensitive indicator of plant photosynthetic performance (KRAUSE; WEISS, 1991; GONÇALVES et al., 2001). Thus, we assume that during the periods analyzed, the plants studied were not subjected to stress conditions that would compromise their photosynthetic performance. This result was corroborated by the $F_{\mathrm{m}} / F_{\mathrm{o}}$ values, which showed no significant seasonal variation.

The decline in photosynthetic assimilation in $S$. guianensis was accompanied by a significant increase in NPQ and carotenoid levels as well as a reduction in the total chlorophyll/carotenoids ratio. NPQ is considered one of the principal mechanisms utilized by plants to mitigate or to prevent the damage caused by excess light energy reaching the photosynthetic apparatus (MAXWELL; JOHNSON, 2000). According to Demmig et al. (1987), carotenoids also aid in the dissipation of excess non-destructive light energy, preventing damage to the PSII. In a similar way, Faria et al. $(1996 ; 1998)$ demonstrated the existence of a high degree of coordination between stomatal behavior and photoprotective mechanisms for the species Quercus ilex and $Q$. suber.

Higher levels of chlorophyll $a$ and the chlorophyll $a / b$ ratio were observed during the dry period. Similar results were reported for Byrsonima sericea under field conditions in the União Biological Reserve (SILVA et al., 2010). However, no change or reduction in chlorophyll 
content of plants under drought stress has been observed in different species, and its intensity depends on stress rate and duration (SCHELMMER et al., 2005; FOTOVAT et al., 2007; ARJENAKI et al., 2012).

We can conclude that the removal of plant litter did not affect gas exchange, chlorophyll $a$ fluorescence, and the content of photosynthetic pigments. However, we found that $X$. sericea was photosynthetically more efficient than $S$. guianensis during the dry period, but neither species was subjected to water-related stress.

\section{Acknowledgements}

We cordially thank the Coordination for the Improvement of Higher Education Personnel (CAPES) for the first author's doctorate fellowship, which helped make this work possible. We are indebted to the technicians and drivers of the Universidade Estadual do Norte Fluminense (UENF) for their support in field work. Thanks go to Douglas Rodrigues Ribeiro, and to the União Biological Reserve - Instituto Chico Mendes de Conservação da Biodiversidade (ICMBio) for providing meteorological data and permission to conduct this research. We also thank the anonymous reviewers for their careful reading of our manuscript and their comments and constructive criticism. Dr. A. Leyva helped with English editing of the manuscript.

\section{References}

ARJENAKI, F. G.; JABBARI, R.; MORSHEDI, A. Evaluation of drought stress on relative water content, chlorophyll content and mineral elements of wheat (Triticum aestivum L.) varieties. International Journal of Agriculture and Crop Sciences, London, v. 4, p. 726-729, 2012.

ATTIGNON, S. E.; WEIBEL, D.; LACHAT, T.; SINSIN, B.; NAGEL, P.; PAVELING, R. Leaf litter breakdown in natural and plantation forests of the Lama forest reserve in Benin. Applied Soil Ecology, Amsterdam, v. 27, n. 2, p. 109-124, 2004.

BAKER, N. R. Light-use efficiency and photoinhibition of photosynthesis in plants under environmental stress. In: SMITH, J. A. C.; GRIFFITHS, H. (Ed.). Water deficit plant responses from cell to community. Oxford: Bios Scientific Publisher, 1993. p. 221-235.

BENKOBI, L.; TRLICA, M.; SMITH, J. L. Soil loss as affected by different combinations of surface litter and rock. Journal of Environmental Quality, Madison, v. 22, p. 657-661, 1993.

BJÖRKMAN, O.; DEMMIG, B. Photon yield of $\mathrm{O}_{2}$ evolution and chlorophyll fluorescence characteristics at $77 \mathrm{k}$ among vascular plants of diverse origins. Planta, New York, v. 170, n. 4, p. 489504, 1987.

BUCKLEY, T. N.; FARQUHAR, G. D.; MOTT, K. A. Carbon-water balance and patchy stomatal conductance. Oecologia, Heidelberg, v. 118, n. 2, p. 132-143, 1999.

CALBO, M. E. R.; MORAES, J. A. P. V. Efeitos da deficiência de água em plantas de Euterpe oleracea (açaí). Revista Brasileira de Botânica, São Paulo, v. 23, n. 3, p. 225-230, 2000.

CAMARA, R. Efeito da serapilheira sobre a dinâmica de nutrientes em plantios de eucalipto em regeneração natural de Mata Atlântica. 2012. 214 f. Tese (Doutorado em Ecologia e Recursos Naturais) - Universidade Estadual do Norte Fluminense, Campos dos Goytacazes. 2012.

CAVENDER-BARES, J.; BAZZAZ, F. A. From leaves to ecosystems: using chlorophyll fluorescence to assess photosynthesis and plant function in ecological studies. In: PAPAGEORGIOU, G. C.; GOVINDJEE (Ed.). Chlorophyll fluorescence: a signature of photosynthesis - Advances in Photosynthesis and Respiration Series. Dordrecht: Springer, 2004. p. 737-755.

CHAPIN III, F. S.; MATSON, P. A.; MOONEY, H. A. Principles of terrestrial ecosystem ecology. New York: Springer-Verlag, 2002. $455 \mathrm{p}$.

DEMMIG, B.; WINTER, K.; KRÜGER, A.; CZYGAN, F. -C. Photoinhibition and zeaxanthin formation in intact leaves. A possible role of the xanthophyll cycle in the dissipation of excess light energy. Plant Physiology, Maryland, v. 84, n. 2, p. 218-224, 1987.

EVARISTO, V. T. Dinâmica da comunidade e das principais populações arbustivo-arbóreas de mata atlântica em plantios abandonados de eucalipto (Corymbia citriodora (Hook.) K.D.Hill \& L.A.S.Johnson). 2008. 158 f. Dissertação (Mestrado em Ecologia e Recursos Naturais) - Universidade Estadual do Norte Fluminense, Campos dos Goytacazes. 2008.

EVARISTO, V. T.; BRAGA, J. M. A.; NASCIMENTO, M. T. Atlantic Forest regeneration in abandoned plantations of eucalypt (Corymbia citriodora) in Rio de Janeiro, Brazil. Interciencia, Caracas, v. 36, n. 6, p. 431-436, 2011.

FARIA, T.; GARCIA-PLAZAOLA, J. I.; ABADIA, A.; CERASOLI, S.; PEREIRA, J. S.; CHAVES, M. M. Diurnal changes in photoprotective mechanisms in leaves of cork oak (Quercus suber) during Summer. Tree Physiology, Victoria, v. 16 n. 1-2, p. 115-123, 1996.

FARIA, T.; SILVÉRIO, D.; BREIA, E.; CABRAL, R.; ABADÍA, A.; ABADÍA, J.; PEREIRA, J. S.; CHAVES, M. N. Differences in the response of carbon assimilation to summer stress (water deficits, high light and temperature) in four Mediterranean tree species. Physiologia Plantarum, Lund, v. 102, n. 3, p. 419-428, 1998.

FERREIRA, W. C.; FERREIRA, M. J.; MARTINS, J. C. Regeneração natural de espécies arbustivo-arbóreas no sub-bosque de Eucalyptus grandis em Mata Ciliar, no município de Lavras, MG. Revista Brasileira de Biociências, Porto Alegre. v. 5, p. 579-581, 2007.

FEYERA, S.; BECK, E.; LÜTTGE, U. Exotic trees as nurse-trees for the regeneration of natural tropical forests. Trees, Berlin, v. 16, n. 4-5, p. 245-249, 2002.

FONSECA, C. R.; GANADE, G.; BALDISSERA, R.; BECKER, C. G.; BOElTER, C. R.; BRESCOVIT, A. D.; CAMPOS, L. M.; FLECK, T.; FONSECA, V. S.; HARTZ, S. M.; JONER, F.; 
KÄFFER, M. I.; LEAL-ZANCHET, A. M.; MARCELLI, M. P.; MESQUITA, A. S.; MONDIN, C. A.; PAZ, C. P.; PETRY, M. V.; PIOVENSAN, F. N.; PUTZKE, J.; STRANZ, A.; VERGARA, M.; VIEIRA, E. M. Towards an ecologically-sustainable forestry in the Atlantic Forest. Biological Conservation, Boston, v. 142, n. 6, p. 1209-1219, 2009.

FOTOVAT, R.; VALIZADEH M.; TOOREHI, M. Association between water-use-efficiency components and total chlorophyll content (SPAD) in wheat (Triticum aestivum L.) under well-watered and drought stress conditions. Journal of Food, Agriculture \& Environment, Helsinki, v. 5, p. 225-227, 2007.

FOWLER, N. L. Microsite requirements for germination and establishment of three grass species. American Midland Naturalist, Notre Dame, v. 115, n. 1, p. 131-145, 1986.

FOWLER, N. L. What is a safe site? Neighbour, litter, germination date and patch effects. Ecology, New York, v. 69, n. 4, p. 947-961, 1988.

GENTY, B.; BRIANTAIS, J.-M.; BAKER, N. R. The relationship between the quantum yield of photosynthetic electron transport and quenching of chlorophyll fluorescence. Biochimica et Biophysica Acta, Amsterdam, v. 990, n. 1, p. 87-92, 1989.

GIT FORESTRY CONSULTING. Global Eucalyptus map. 2009. Disponível em <http:/www.gitforestry.com/downloads/GIT_ Forestry_Global_Eucalyptus_Map_2009_Marketing_Campaign_ ENG.pdf $>$. Acesso em: 03 julho 2013.

GONÇALVES, J. F. C.; MARENCO, R. A.; VIEIRA G. Concentration of photosynthetic pigments and chlorophyll fluorescence of mahogany and tonka bean under two light environments. Revista Brasileira de Fisiologia Vegetal, Campinas, v. 13, n.2, p. 149-157, 2001.

GONÇALVES, J. F. C.; SILVA, C. E. M.; GUIMARÃES, D. G. Fotossíntese e potencial hídrico foliar de plantas jovens de andiroba submetidas à deficiência hídrica e à reidratação. Pesquisa Agropecuária Brasileira, Brasília. v. 44, n. 1, p. 8-14, 2009.

KNORR, M.; FREY, S. D.; CURTIS, P. S. Nitrogen additions and litter decomposition: a meta-analysis. Ecology, New York, v. 86, n. 12, p. 3252-3257, 2005.

KRAMER D. M.; JOHNSON, G.; KIIRATS, O.; EDWARDS, G. E. New fluorescence parameters for the determination of $Q_{A}$ redox state and excitation energy fluxes. Photosynthesis Research, Amsterdam, v. 79, p. 209-218, 2004.

KRAUSE, G. H.; WEIS, E. Chlorophyll fluorescence and photosynthesis: the basics. Annual Review of Plant Physiology and Plant Molecular Biology, Palo Alto, v. 42, p. 313-349, 1991.

LAGE-PINTO, F.; BERNINI, E.; OLIVEIRA, J. G.; VITÓRIA, A. P. Photosynthetic analyses of two native Atlantic Forest species in regenerative understory of eucalyptus plantation. Brazilian Journal of Plant Physiology, Campos dos Goytacazes, v. 24, n. 2, p. 95-106, 2012.

LU, C.; ZHANG, J. Effects of water stress on photosystem II photochemistry and its thermostability in wheat plants. Journal of Experimental Botany, Oxford, v. 50, n. 336, p. 1199-1206, 1999.

MARTINEZ, C. A.; OLIVEIRA, E. D.; LEGRACIE, J. R.; APPROBATO, A. The effects of elevated $\mathrm{CO}_{2}$ on tropical trees are related to successional status and soil nutritional conditions. In: ALLEN, J. F.; GANTT, E.; GOLBECK, J. H.; OSMOND, B. (Ed.).
Photosynthesis: energy from the sun. 14th International Congress on Photosynthesis. Dordrecht: Springer, 2008. p. 1380-1382.

MAXWELL, K.; JOHNSON, G. N. Chlorophyll fluorescence: a practical guide. Journal of Experimental Botany, Oxford, v. 51, n. 345 , p. 659-668, 2000.

MMA-ICMBIO. Plano de manejo da Reserva Biológica União Resumo Executivo. 2008. Ministério do Meio Ambiente - Instituto Chico Mendes de Conservação da Biodiversidade. Disponível em $<$ http://www.icmbio.gov.br/portal/images/stories/ imgs- unidadescoservacao/RESUMO\%20EXECUTIVO_rebio.pdf $>$. Acesso em: 17 jun. 2014.

MO, J.; BROWN, S.; PENG, S.; KONG, G. Nitrogen availability in disturbed, rehabilitated and mature forests of tropical China. Forest Ecology Management, Amsterdam, v. 175, n. 1-3, p. 573583, 2003.

NILSEN, E. T.; ORCUTT, D. M. The physiology of plants under stress: abiotic factors. New York: John Wiley, 1996. p. 230.

NISHIMURA, H.; NAKAMURA, T.; MIZUTANI, J. Allelopathic effects of $p$-methane-3,8-diols in Eucalyptus citriodora. Phytochemistry, Oxford, v. 23, n. 12, p. 2777-2779, 1984.

NÓBREGA, A. M. F.; VALERI, S. V.; PAULA, R. C.; SILVA, A. $\mathrm{S}$. Natural regeneration in Forest remainders and reforested areas of "Mogi-Guaçu" river floodplain in Luiz Antônio county, São Paulo, Brazil. Revista Árvore, Viçosa, v. 32, p. 909-920, 2008.

PONGE, J-F.; ARPIN, P.; VANNIER, G. Collembolan response to experimental perturbations of litter supply in a temperate forest ecosystem. European Journal of Soil Biology, Braunschweig, v. 29, n. 3-4, p. 141-153, 1993.

PRESCOTT, C. E.; BLEVINS, L. L.; STALEY, C. Litter decomposition in British Columbia forests: controlling factors and influences of forestry activities. BC Journal of Ecosystems and Management, Québec, v. 5, n. 2, p. 44-57, 2004.

REIS, F. O.; CAMPOSTRINI, E. Leaf gas exchange and potential photochemical efficiency of field-grown papaya plants. Bragantia, Campinas, v. 67, n. 4, p. 815-822, 2008.

RIBEIRO, A. C. C. Efeito da remoção da serapilheira no estabelecimento de plântulas de espécies nativas da Mata Atlântica em plantios de eucalipto Corymbia citriodora (Hook) L. A. Jonhson \& K. D. Hill, na Reserva Biológica União, Rio das Ostras, RJ). 2007. 61 f. Dissertação (Mestrado em Ecologia e Recursos Naturais) - Universidade Estadual do Norte Fluminense, Campos dos Goytacazes. 2007.

RIBEIRO, M. C.; METZGER, J. P.; MARTENSEN, A. C.; PONZONI, F.; HIROTA, M. M. Brazilian Atlantic Forest: how much is left and how is the remaining forest distributed? Implications for conservation. Biological Conservation, Boston, v. 142, n. 6, p. 1141-1153, 2009.

ROSENQUIST, E.; WINGSLE, G.; ORGEN, E. Photoinhibition of photosynthesis in intact willow leaves in response to moderate changes in light and temperature. Physiologia Plantarum, Lund, v. 83, n. 3, p. 390-396, 1991.

RUF, A.; KUZYAKOV, Y.; LOPATOVSKAYA, O. Carbon fluxes in soil food webs of increasing complexity revealed by ${ }^{14} \mathrm{C}$ labelling and ${ }^{13} \mathrm{C}$ natural abundance. Soil Biology \& Biochemistry, Oxford, v. 38, n. 8, p. 2390-2400, 2006.

SANGHA, K. K.; JALOTA, R. K.; MIDMORE, D. J. Litter production, decomposition and nutrient release in cleared and 
uncleared pasture systems of central Queensland, Australia. Journal of Tropical Ecology, London, v. 22, n. 2, p. 177-189, 2006.

SAYER, E. J. Using experimental manipulation to assess the roles of leaf litter in the functioning of forest ecosystems. Biology Review, London, v. 80, n. 1, p. 1-31, 2006.

SAYER, E. J.; TANNER, E. V. J. Experimental investigation of the importance of litterfall in lowland semi-evergreen tropical forest nutrient cycling. Journal of Ecology, London, v. 98, n. 5, p. 10521062, 2010.

SCALON, M. C.; ROSSATTO, D. R.; FRANCO, A. C. Do litter manipulations affect leaf functional traits of savanna woody plants? Plant Ecology, Dordrecht, v. 215, p. 111-120, 2014.

SCHLEMMER, M. R.; FRANCIS, D. D.; SHANAHAN J. F.; SCHEPERS, J. S. Remotely measuring chlorophyll content in corn leaves with differing nitrogen levels and relative water content. Agronomy Journal, Madison, v. 97, p. 106-112, 2005.

SILVA, A. S.; OLIVEIRA, J. G.; DA CUNHA, M.; VITÓRIA, A. P. Photosynthetic performance and anatomical adaptations in Byrsonima sericea DC. under contrasting light conditions in a remnant of the Atlantic Forest. Brazilian Journal of Plant Physiology, Campos dos Goytacazes, v. 22, n. 4, p. 245-254, 2010.

SUGUITURU, S. S.; SILVA, R. R.; SOUZA, D. R.; MUNHAE, C. B.; MORINI, M. S. C. Ant community richness and composition across a gradient from Eucalyptus plantations to secondary Atlantic Forest. Biota Neotropica, Campinas, v. 11, n. 1, p. 369-376, 2011.

THOMPSON, W. A.; KRIEDEMANN, P. E.; CRAIG, I. E. Photosynthetic response to light and nutrients in sun-tolerant and shade-tolerant rainforest trees I - Growth leaf anatomy and nutrient content. Australian Journal of Plant Physiology, East Melbourne, v. 19, n. 1, p. 1-18, 1992.

VAN KOOTEN, O.; SNEL, J. F. H. The use of chlorophyll fluorescence nomenclature in plant stress physiology. Photosynthesis Research, Netherlands, v. 25, n. 3, p. 147-150, 1990.
VElOSO, H. P.; RANGEL-FILHO, A. L. R.; LIMA, J. C. A. Classificação da vegetação brasileira adaptada a um sistema universal. Rio de Janeiro: IBGE, 1991. 123 p.

VILLELA, D. M.; NASCIMENTO, M. T.; REZENDE, C. E.; NASCIMENTO, A. C.; MAZUREC, A. P.; TESCH, E. Effects of regeneration of native species under Eucalyptus plantations, after 6-yrs of abandonment, on nutrients concentrations and quantities of litter layer in União Biological Reserve, Rio de Janeiro State, Brazil. In: INTERNATIONAL SYMPOSIUM OF ENVIRONMENTAL GEOCHEMISTRY IN TROPICAL COUNTRIES, 4, 2004, Búzios. Resumos... Niteroi: UFF/Programa de Geoquímica, 2004. p. $202-$ 205.

VITOUSEK, P. M. Litterfall, nutrient cycling, and nutrient limitation in tropical forests. Ecology, New York, v. 65, p. 285-298, 1984

WELLBURN, A. R. The spectral determination of chlorophylls $a$ and $b$, as well as total carotenoids, using various solvents with spectrophotometers of different resolution. Journal of Plant Physiology, Tübingen, v. 144, n. 3, p. 307-313, 1994.

WOOD, T. E.; LAWRENCE, D.; CLARK, D. A.; CHAZDON, R. L. Rain forest nutrient cycling and productivity in response to large-scale litter manipulation. Ecology, New York, v. 90, n. 1, p. 109-121, 2009.

XIONG, S.; NILSSON, C. The effects of plant litter on vegetation: a meta-analysis. Journal of Ecology, London, v. 87, n. 6, p. $984-$ 994, 1999.

ZHANG, C.; FU, S. Allelopathic effects of leaf litter and live roots exudates of Eucalyptus species on crops. Allelopathy Journal, New York, v. 26, n.1, p. 91-100, 2010. 